\title{
Impacts of COVID-19 on the Fisheries and Aquaculture Sector in Developing Countries and Ways Forward
}

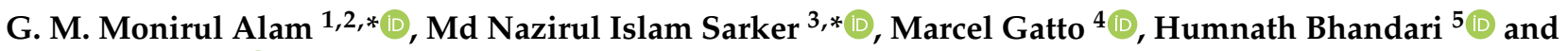 \\ Diego Naziri ${ }^{4,6}$ (1)
}

1 Faculty of Agricultural Economics and Rural Development, Bangabandhu Sheikh Mujibur Rahman Agricultural University (BSMRAU), Gazipur 1706, Bangladesh

2 School of Commerce, University of Southern Queensland, Toowoomba, QLD 4350, Australia

3 School of Political Science and Public Administration, Neijiang Normal University, Neijiang 641112, China

4 International Potato Center (CIP), Hanoi 100000, Vietnam; M.Gatto@cgiar.org (M.G.); D.Naziri@cgiar.org (D.N.)

5 International Rice Research Institute (IRRI), Dhaka 1213, Bangladesh; h.bhandari@irri.org

6 Natural Resources Institute (NRI), University of Greenwich, Chatham ME4 4TB, UK

* Correspondence: gmalam@bsmrau.edu.bd (G.M.M.A.); sarker.scu@yahoo.com (M.N.I.S.)

Citation: Alam, G.M.M.; Sarker, M.N.I.; Gatto, M.; Bhandari, H.; Naziri, D. Impacts of COVID-19 on the Fisheries and Aquaculture Sector in Developing Countries and Ways Forward. Sustainability 2022, 14, 1071. https://doi.org/10.3390/su14031071

Academic Editor: Mario D'Amico

Received: 16 October 2021

Accepted: 17 November 2021

Published: 18 January 2022

Publisher's Note: MDPI stays neutral with regard to jurisdictional claims in published maps and institutional affiliations.

Copyright: (c) 2022 by the authors. Licensee MDPI, Basel, Switzerland. This article is an open access article distributed under the terms and conditions of the Creative Commons Attribution (CC BY) license (https:/ / creativecommons.org/licenses/by/ $4.0 /)$.

\begin{abstract}
Fish is a major source of food and nutritional security for subsistence communities in developing countries, it also has linkages with the economic and supply-chain dimensions of these countries. Burgeoning literature has revealed the adverse impacts of COVID-19 on the fisheries and aquaculture sector, which serves as the major source of income and employment for numerous people globally. This study has employed a systematic literature review of the overall impacts of COVID-19 on the fisheries and aquaculture sector in developing countries using the PRISMA approach. This study reveals that COVID-19 has posed numerous challenges to fish supply chain actors, including a shortage of inputs, a lack of technical assistance, an inability to sell the product, a lack of transportation for the fish supply, export restrictions on fish and fisheries products, and a low fish price. These challenges lead to inadequate production, unanticipated stock retention, and a loss in returns. COVID-19 has also resulted in food insecurity for many small-scale fish growers. Fish farmers are becoming less motivated to raise fish and related products as a result of these cumulative consequences. Because of COVID-19's different restriction measures, the demand and supply sides of the fish food chain have been disrupted, resulting in reduced livelihoods and economic vulnerability. In order to assist stakeholders to cope with, adapt to, and build resilience to pandemics and other shocks, this study offers policy recommendations to address the COVID-19-induced crisis in the fisheries and aquaculture sector.
\end{abstract}

Keywords: aquaculture; small-scale fisheries; fish-based industry; fish-food supply chain

\section{Introduction}

The COVID-19 pandemic had spread all over the world since its first detection in December of 2019 [1]. However, developing countries are more vulnerable to the adverse impacts of the pandemic than developed countries, due to their limited resources, expertise, and technologies. COVID-19 has had an influence on all sectors of the economy; the fisheries and aquaculture sector in particular has faced great difficulty, mainly due to the perishability of the product [2]. The fisheries and aquaculture industry provides significant employment opportunities all around the world. In 2018, the primary sector of fisheries and aquaculture employed a total of 59.5 million people, of which 85 percent were located in Asia [3].

Fish and fish products constitute an important part of a healthy diet. In 2018, around 88 percent of total fish production (179 million tons) was used for direct human consumption [3]. Fish is often a fishing community's primary source of protein, fatty acids, and micronutrients [3]. Fish do not play a role in the transfer of COVID-19 to humans in terms 
of epidemiology. However, false perceptions about fish and the spread of COVID-19 have contributed to a decrease in the consumption of fish in some cases, such as in Bangladesh and China [4]. Because fish is an important food source for a large portion of the world's population, the business of fishing requires changes, especially now during the current pandemic. Many of the governmental measures that have been introduced to limit the spread of COVID-19 have caused significant disruptions to human movement, physical business contact and the transport of goods [5]. Many countries and regions (for example, Bangladesh, India, Pakistan, and China) continue to maintain isolation measures and movement restrictions that limit people's ability to roam and interact.

Domestic and international trade has been hindered or stopped as a result of the lockdown and, as a result of this, the practically of the supply chain for all food goods has been compromised [1]. Furthermore, due to the restrictions, restaurants and hotels are legally bound to close their doors. The demand for fish and fish products has decreased as a result of this [6]. By disrupting fish supply and demand, fish distribution, labor, and production, COVID-19 exposes the existing vulnerabilities in small-scale fisheries, putting small-scale farmers' livelihoods at risk [7]. The many value chains within the fisheries and aquaculture sector were also subject to the inevitable disruptions to international and domestic transportation; these disruptions have affected the supply of raw materials for processing, the supply of production inputs, and the shipping of the finished products for both export and domestic consumption [8]. Farm-made inputs, such as seed stock and feed, have become unavailable due to the stringent restrictions that have been placed on the movement of materials and persons, including workers [9]. Small-scale fish farmers have lost money because they either had to sell off their fish or couldn't sell their fish at all. Fish farmers could not harvest their fish in order to be able to begin a new production cycle, leading to a reduction in fish availability and the loss of downstream and upstream employment opportunities [7]. According to Waiho et al. [10], COVID-19 has depressed the demand for fish and fishery products and negatively impacted the supply chain, forcing hatcheries to close, feed imports to halt, and many value chain entities to lose money right from the start of the culture season. Medium and small businesses and seafood producers have been hit particularly hard, many of them are still unable to resume their normal operations [11]. COVID-19, in fact, has posed complex and long-term challenges for the aquaculture value chains' continued operations and the livelihoods of the millions of people who rely on them [12]. However, the major impact on supply chains and demand is not from COVID-19 itself, but instead from the measures that have been introduced in order to control it.

There is much burgeoning literature on the impacts of COVID-19; in the fisheries and aquaculture sector these studies particularly focus on local case studies in countries such as the USA [13], China [14], Canada [15], Indonesia [16], Malaysia [10], Kenya [10], Thailand [17], and Bangladesh [4,18,19]. However, a global perspective is still missing. As a provider of an essential food item, understanding how COVID-19 affects the fisheries sector and the supply chain of fish, and to what extent the different stakeholders can be assisted to overcome this situation, is crucial. Since each fish food chain comprises several stakeholders, an understanding of the impacts and challenges that are influencing the input suppliers, fish farmers, traders, processors, exporters and importers is needed. The existing studies focus on many important issues, such as the overall impact of COVID-19 on smallscale fisheries [9,19-21], aquaculture (including when COVID-19 synergizes its impacts with anthropogenic stressors) [10,22], vulnerability [23], resilience [7,24], consumption patterns [4,25], fish food [4], seafood [26], and the food system [19]. However, there is a lack of a thorough study that focuses on COVID-19's overall effect on the fisheries sector and the fish food chain; this is a study that is needed in order to gain insights that can assist policy design in order to improve the sector's resilience. Therefore, the aim of the present study is to extend the understanding of the impacts of COVID-19 on the fisheries and aquaculture sector, through a systematic literature review, to help fishery-dependent communities to cope, adapt, and build resilience, particularly in developing countries. 


\section{Materials and Methods}

\subsection{Research Design}

This study has applied a systematic review approach, which included creating a review protocol and searching for the most relevant literature. According to Fink [27], a systematic literature review is "a systematic, explicit, comprehensive, and reproducible method for identifying, evaluating, and synthesizing the existing body of completed and recorded work produced by researchers, scholars, and practitioners". The recommendations that we followed for the collection of our data were based on the Preferred Reporting Items for Systematic Reviews and Meta-Analyses (PRISMA) [28]. PRISMA is a widely used tool for the systematic review of literature, it includes four main steps referred to as identification, screening, eligibility and included. A number of checklists were utilized as we followed these four steps.

\subsection{Eligibility Criteria}

The following criteria were used to decide which articles would be included in our review: the relevance of the article to the fisheries and aquaculture-related disciplinary field, the published article's language, the presence of references to the impact of COVID-19 or the fish food supply chain, and the date of publication. The present analysis has only looked at original, peer-reviewed journal articles that are written in English. This research has spanned the last two years, from January 2020 to August 2021. This study considers articles that focused on the impacts of COVID-19 on the fisheries sector and the fish food supply chain.

\subsection{Search Strategy}

After referring to several common databases, the main search string was developed in order to suit the databases' specifications. The string includes terms such as impact of COVID-19, fisheries, small-scale fish farming, aquatic fish food, fish supply chain, aquaculture, seafood and food system. To obtain the documents for use in our qualitative analysis, well-known databases such as Web of Science, Scopus, and the first 10 pages of Google Scholar were used. The research protocol used in this study is outlined in Table 1.

Table 1. Summary of research protocol.

\begin{tabular}{|c|c|}
\hline Items & Description \\
\hline Selected databases & Web of Science, Scopus, and first 10 pages of Google Scholar \\
\hline Publication criteria & Only peer-reviewed journals \\
\hline Language & Articles published in English \\
\hline Time duration & From January 2020 to August 2021 \\
\hline Search terms & $\begin{array}{l}\text { Impact of COVID-19, fisheries, small-scale fish farming, aquatic fish } \\
\text { food, fish supply chain, aquaculture, seafood, and food system }\end{array}$ \\
\hline Search fields & Title, abstract, and keywords \\
\hline Inclusion criteria & $\begin{array}{c}\text { Papers focusing on the impact of COVID-19 on fisheries, aquaculture, } \\
\text { and fish food supply chain }\end{array}$ \\
\hline Regional focus & Developing countries \\
\hline
\end{tabular}

\subsection{Data Extraction}

Data were obtained from the selected documents in a consistent manner. The author, year of publication, nature of the study, sample size, study location, research methodology, and results obtained were all included in the data that we procured from each study.

\subsection{Systematic Review Results}

This study obtained 253 documents from the core databases identified above and 8 additional papers from sources that were discovered during the identification stage. Screening procedures were then followed, which culminated in the removal of 160 documents due to a lack of details that were relevant to this study. The third PRISMA stage, 
eligibility, was then commenced and 54 of the papers were excluded due to a lack of full text, general non-relevancy, or a lack of references to the impact of COVID-19, fish supply chains, or aquaculture issues. The remaining 47 documents then became the focus of our detailed review (Figure 1).

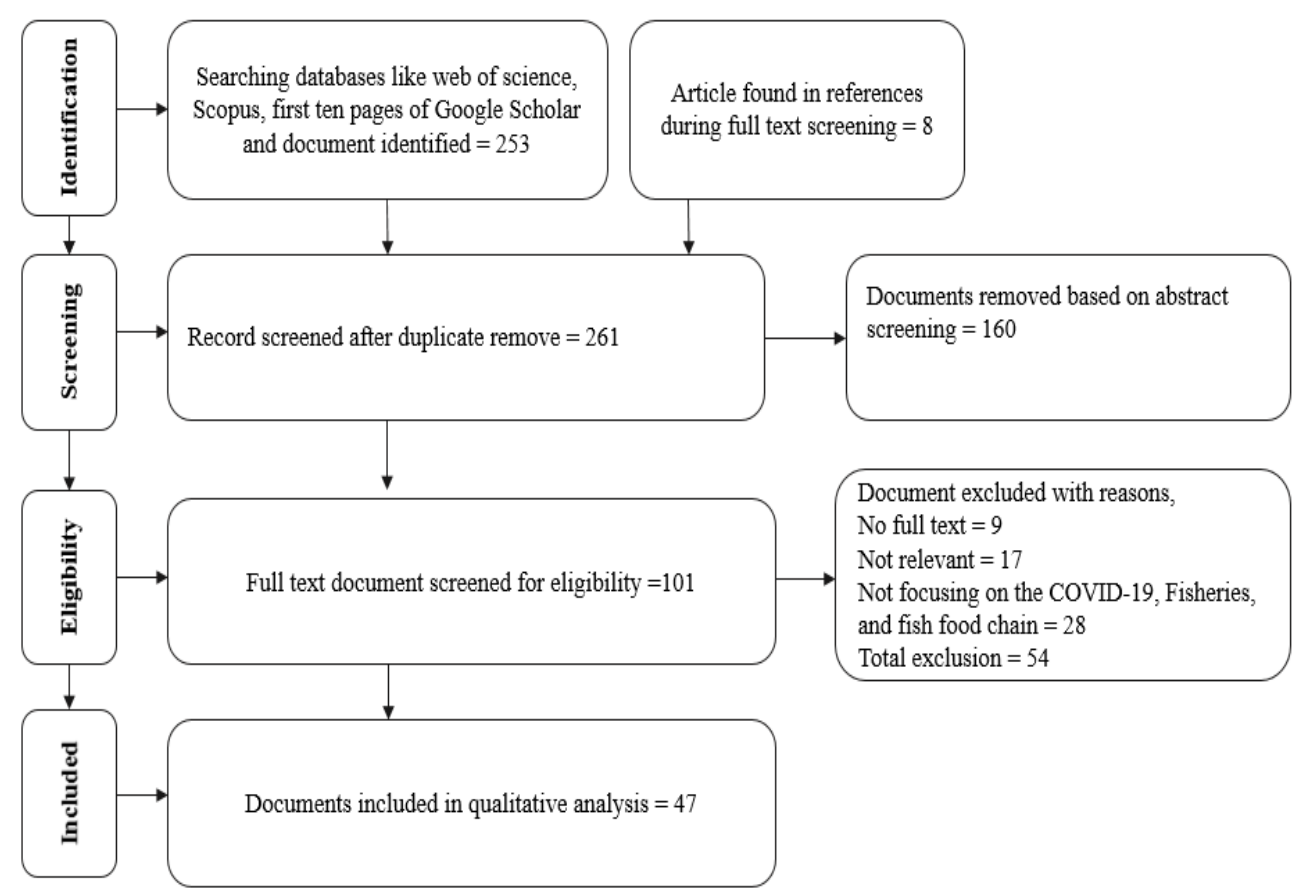

Figure 1. Selection of documents for qualitative analysis.

\section{Results}

\subsection{Summary of the Impacts of COVID-19 on the Fisheries Sector}

The effects of COVID-19 on the fisheries and aquaculture sector are manifold (Table 2). The present study has identified the key affected domains of the fisheries sector, these are the stakeholders, freshwater aquaculture, brackish water aquaculture, river and naturally sourced fisheries, offshore fisheries, and industry. Fishermen, farmers, auctioneers, and traders are the main stakeholders. The major impacts felt at the stakeholder level are the limited access to livelihood capital, disruption of strategies for securing a livelihood, increased vulnerability of livelihoods, and increase in food and nutritional insecurity $[4,29,30]$. At the freshwater aquaculture level, the restriction measures that have been put in place to stop the spread of COVID-19 are responsible for increasing the cost of inputs and transportation, hampering the availability of seed stock, reducing demand and price, and increasing the burden of maintaining unsold stock. Brackish water aquaculture and river and naturally sourced fisheries are facing the same challenges, along with less regulatory enforcement. From an ecological perspective, only offshore aquaculture has received a positive impact from COVID-19. Aquaculture at the industry level has also faced many challenges, such as the need to reduce the production of processed food items, increase the price of raw materials, limit sales, and restrain international trade (Table 2).

Furthermore, fish and fish products have experienced a sharp decline in rates of export. For example, in Turkey, the pandemic has primarily impacted exporters, who have experienced a 65 percent drop in their trade volume. Wholesalers have also been impacted, experiencing a 35 percent reduction in their trade volume, and so too have retailers, who have experienced a reduction of 35 percent [45]. In Indonesia, the number of active fishers and fish dealers has decreased by $90 \%$ due to the COVID-19 pandemic [16]. 
Table 2. Summary of the impacts of COVID-19 on fisheries and aquaculture production based on literature review.

\begin{tabular}{|c|c|c|}
\hline $\begin{array}{l}\text { Major Domains of Fisheries } \\
\text { and Aquaculture Production }\end{array}$ & Impacts of COVID-19 & Sources \\
\hline Stakeholders & $\begin{array}{ll}\text { - } & \text { Limited access to livelihood } \\
\text { capital } \\
\text { - } \\
\text { Disruption of strategies for } \\
\text { securing livelihood } \\
\text { - } \\
\text { Increased vulnerability of } \\
\text { livelihoods } \\
\text { - Increased food and nutritional } \\
\text { insecurity }\end{array}$ & $\begin{array}{l}\text { Belton [31] } \\
\text { Stokes et al. [12] } \\
\text { Ferrer et al. [9] } \\
\text { Kumaran et al. [32] }\end{array}$ \\
\hline Freshwater aquaculture & $\begin{array}{ll}\text { - } & \text { Increased cost of inputs and } \\
\text { transportation } \\
\text { - } \\
\text { Hampered availability of seed } \\
\text { stock } \\
\text { - } \quad \text { Lower demand and price } \\
\text { Increased burden of maintaining } \\
\text { unsold stock }\end{array}$ & $\begin{array}{l}\text { Islam et al. [18] } \\
\text { Seshagiri et al. [33] } \\
\text { Cooke et al. [34] } \\
\text { Fiorella et al. [6] } \\
\text { Stokes et al. [12] }\end{array}$ \\
\hline Brackish water aquaculture & $\begin{array}{l}\text { - } \quad \text { Increased transportation cost } \\
\text { Reduced sales and falling prices }\end{array}$ & $\begin{array}{l}\text { Kumaran et al. [32] } \\
\text { Islam et al. [18] } \\
\text { Manlosa et al. [35] }\end{array}$ \\
\hline $\begin{array}{l}\text { River and naturally sourced } \\
\text { fisheries }\end{array}$ & $\begin{array}{ll} & \text { Increased positive impact on } \\
& \text { natural sources } \\
\bullet & \text { Lower demand and price } \\
\bullet & \text { Expensive transportation } \\
\text { - } & \text { Reduced regulatory enforcement }\end{array}$ & $\begin{array}{l}\text { Waibel et al. [36] } \\
\text { Newton et al. [14] } \\
\text { Islam et al. [18] } \\
\text { Stokes et al. [12] }\end{array}$ \\
\hline Offshore fisheries & $\begin{array}{ll}\text { - } & \text { Positive ecological impact on stock } \\
\text { - } & \text { Lower demand and price } \\
\text { - } & \text { Highed transportation cost }\end{array}$ & $\begin{array}{l}\text { Andrews et al. [37] } \\
\text { Shenoy \& Rajpathak [38] } \\
\text { Marschke et al. [39] } \\
\text { Asante, \& Sabau [40] }\end{array}$ \\
\hline Industry & $\begin{array}{ll}\text { - } & \text { Reduced production of processed } \\
\text { food items } \\
\text { - } & \text { Increased price of raw materials } \\
\text { - } & \text { Need to limit sales } \\
\text { - Need to limit international trade }\end{array}$ & $\begin{array}{l}\text { Fernández-González, \& } \\
\text { Pérez-Vas [41] } \\
\text { Hasan et al. [42] } \\
\text { Kaewnuratchadasorn et al. } \\
\text { [43] } \\
\text { Paradis et al. [44] }\end{array}$ \\
\hline
\end{tabular}

\subsection{COVID-19's Impacts on the Aquatic Food Supply Chain}

The present study has identified several of the major impacts of COVID-19 on the aquatic food supply chain (Table 3). The key domains that have been affected are fishing, aquaculture production, processors and cold storage. At the fishing level, farmers are facing limited access to capture fisheries, less time to catch the fish, expensive labor, and travel restrictions. Similarly, at the production level, stakeholders are experiencing the higher costs of inputs and transportation, less demand, reductions in the price of the product, and undesired stock. At the processor level, there are also several challenges such as expensive transportation, dropping demand and prices, expensive inputs and restrictions on transportation (Table 3). The aquatic food supply chain's stakeholders are also facing limited access to cold storage facilities and are therefore incurring losses due to the perishability of the product. 
Table 3. Summary of the impacts of COVID-19 on the aquatic food supply chain.

\begin{tabular}{|c|c|c|}
\hline $\begin{array}{l}\text { Major Domains of } \\
\text { Supply Chain }\end{array}$ & Impacts of COVID-19 & Sources \\
\hline Fishing & $\begin{array}{ll}\text { - } & \text { Limited access to capture } \\
\text { fisheries } \\
\text { - } \quad \text { Reduced duration of catching } \\
\text { - } \quad \text { Increased labor cost } \\
\text { - } \quad \text { Travel restrictions }\end{array}$ & $\begin{array}{l}\text { Fiorella et al. [6] } \\
\text { Campbell et al. [20] } \\
\text { Ruiz-Salmón et al. [26] } \\
\text { Paradis et al. [44] }\end{array}$ \\
\hline Aquaculture production & $\begin{array}{ll}\text { - } & \text { Increased cost of inputs and } \\
\text { transportation } \\
\text { - } & \text { Undesired seed stock } \\
\text { - } & \text { Reduced demand and price } \\
\text { - } & \text { Increased burden of } \\
& \text { maintaining unsold stock }\end{array}$ & $\begin{array}{l}\text { Cooke et al. [34] } \\
\text { Manlosa et al. [35] } \\
\text { Sarà et al. [22] } \\
\text { Islam et al. [18] }\end{array}$ \\
\hline Processors & $\begin{array}{ll}\text { - } & \text { Transportation cost increased } \\
\text { - } & \text { Decline of rates of sale and } \\
\text { - } & \text { Exice } \\
\text { - } & \text { Limited transportation due to } \\
& \text { restrictions }\end{array}$ & $\begin{array}{l}\text { White et al. [46] } \\
\text { Bennett et al. [47] } \\
\text { Fiorella et al. [6] } \\
\text { Kumaran et al. [32] }\end{array}$ \\
\hline Cold storage facilities & $\begin{array}{l}\text { Less access to cold storage } \\
\text { facilities } \\
\text { Unexpected loss due to the } \\
\text { perishable nature of the } \\
\text { product }\end{array}$ & $\begin{array}{l}\text { Fahlevi et al. [48] } \\
\text { Kumaran et al. [32] } \\
\text { Kaewnuratchadasorn et al. } \\
\text { [43] }\end{array}$ \\
\hline
\end{tabular}

\section{Discussion}

\subsection{Impacts on Fisheries' Production and Activity}

4.1.1. The Negative Impacts

Following the discovery of COVID-19, lockdown measures were implemented in many regions to prevent the disease from spreading; however, these precautions have caused disruption to all aspects of the aquatic food supply chain, including fishing, aquaculture production, fish processing, and the market for fish products [2]. Some key negative impacts have been described below:

\section{(a) Impact on fishing activity}

Fishing activity has decreased as a result of the social distancing practices and additional COVID-19 restrictions that have been implemented [18]. Since the World Health Organization proclaimed COVID-19 to be a pandemic, global industrial fishing activities have decreased by $10 \%$ or more in some areas, relative to the previous year's average [3]. Fisheries were outlawed in several nations, such as India, as part of the mobility limitations that were imposed to counteract the developing pandemic [47]. The fisheries industry was severely impacted by the lower worldwide demand for fish and related market disruptions and, as a result, most fishermen were unable to sell their catch directly [19]. In areas of high fish production, unsold fish was consumed in order to support food security. Furthermore, many employees who were working in the processing, harvesting, and marketing of aquatic food have lost their jobs, and their income has ceased, particularly in developing nations $[19,47]$. Finally, the biggest impediment to fishing operations is the lack of ice, gasoline, gear, bait, and other supplies, as well as manpower constraints [12]. It should be noted that, under the emergency situation created by COVID-19, there was no monitoring or supervision of fishing activities, which might have enhanced the risk of illegal fishing [18].

(b) Impacts on aquaculture farms

Due to the significant drop in the market's demand for fish and the limited transportation options that were available during the lockdown, fish farms have had difficulty in 
collecting and selling their goods [2]. As farmers have been unable to sell their products there has been an increase in live fish stock levels and a lengthening of the fish culture period, both of which have negatively impacted the feed conversion ratios, the ability to restock and, ultimately, the farms' profitability. Accordingly, feeding expenditures have grown, as has the risk of fish mortality. There is no way to start a new farming cycle, as the farmers are unable to harvest their current produce. As a result, they must attempt to sell their produce at a lower price, which results in negative economic consequences for the farmers' livelihoods $[3,19]$. Due to the stringent restrictions on movement, producers have reported difficulties with production inputs, such as seed stock and fingerling shortages, and limited access to consulting or engineering services, feed, labor, medicine, chemicals, and vaccines. The lack of basic products such as medicine has resulted in poor water quality management and a higher prevalence of infection in aquaculture operations [17,35].

\subsubsection{Common Challenges Faced by Small-Scale Fisheries}

In many cases within different developing countries, COVID-19 has severely affected the local and commercial aquatic food production systems, both directly and indirectly (Table 4). Marginal fish farmers often raise fish primarily for personal consumption and then sell the surplus to supplement their income. During lockdown, they could not collect their inputs on time and did not receive the customary level of support from technical experts. The biggest problem faced by fish farmers and business people in the fisheries sector was the transportation of fish, fingerlings, feed, and other inputs [49]. During lockdown, drivers of local-delivery vehicles such as trucks and pickups were frightened to deliver fish, fingerlings, feed, and other items and this caused subsequent disruption to the supply chain [18]. Besides this, after the delivery of fish was complete, many empty vehicles incurred fines on their return journey. These impacts on transportation have negatively influenced the fish landing centres, wholesale markets, and retail market [35]. Due to the spread of the pandemic, many workers were also unwilling to work, or demanded higher wages [42]. Due to a shortage of liquid capital, some of the actors within the aquatic food supply chain could not properly perform their functions [29]. Farmers, laborers, hatchery owners, and other individuals who were linked to the supply chain suffered losses due to these issues, which could continue to have a long-term influence on the fisheries sector [39]. The long-term effects of this situation are the increase in the vulnerability of the aquaculture sector and increased challenges to the resilience of the people involved in it.

Table 4. Summary of the common challenges faced by small-scale fisheries.

\begin{tabular}{|c|c|}
\hline Common Challenges & Sources \\
\hline Difficulty of maintaining proper timing for fish farming & Manlosa et al. [35] \\
\hline Scarcity of input collection & Sunny et al. [19] \\
\hline Expensive input & Islam et al. [18] \\
\hline Unexpectedly unsold fish stock & Zorriehzahra et al. [50] \\
\hline Disease attack & Kumaran et al. [32] \\
\hline Inability to maintain daily farming expenses & Islam et al. [18] \\
\hline Shortage of labor & Mandal et al. [4] \\
\hline $\begin{array}{l}\text { The unwillingness of labor force due to fear of a } \\
\text { COVID-19 infection }\end{array}$ & Plagányi et al. [11] \\
\hline Lack of minimum capital & Kaewnuratchadasorn et al. [43] \\
\hline Poor support from the service provider & Hamzah \& Nurdin [24] \\
\hline Deficient demand for fry and processed fish & Waiho et al. [10] \\
\hline Low demand for and price of hatchery product & Zorriehzahra et al. [50] \\
\hline Expensive fish feed & Wiradana et al. [16] \\
\hline Low demand from consumer & Sunny et al. [19] \\
\hline Meagre price & Campbell et al. [20] \\
\hline Expensive transportation and restrictions & Islam et al. [18]; Belton et al. [51] \\
\hline
\end{tabular}




\subsection{Disruption to the Aquatic Food Supply Chain}

Global, regional, and local markets are all a part of the aquatic food supply chain. The operations required to transport fish and fish products from the supplier to the end consumer are extensive. Across the globe, the technologies used for this purpose range from traditional to highly industrial. The effects of COVID-19 have affected every activity in the supply chain (Figure 2). Within Figure 2, the bold arrows on the left side show the main points at which COVID-19 impacts the primary, secondary, retailer and export markets.

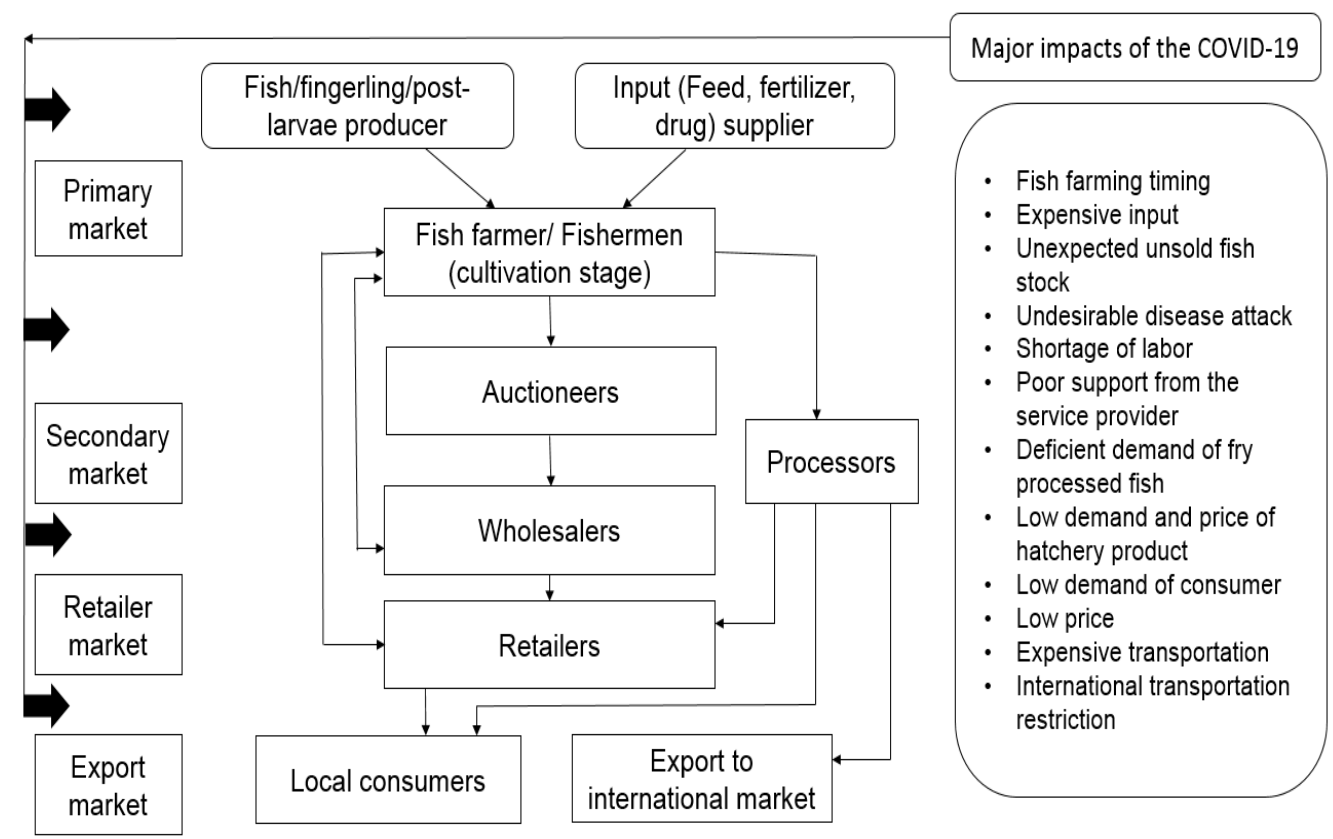

Figure 2. Disruption of aquatic food supply chain. Source: from existing literature.

\subsubsection{Fishing}

Due to the shutdown caused by COVID-19, fishing activity has been hampered by a lack of supplies such as gear, ice, and bait and the inability of suppliers to offer inputs on credit. Fishing operations have also been hampered by a labor shortage caused by transport limitations $[10,17-19,34,52]$.

\subsubsection{Aquaculture Production}

Due to market disruptions, fish farmers have been unable to sell their fish. As a result, they have been stockpiling large quantities of live fish, the storage of which will be required for an indefinite period, raising expenses and expenditures, and increasing hazards [6]. Due to the restrictions placed on foreign markets, the export of food products such as Pangasius fish has been hampered. Furthermore, the closing of restaurants and hotels has also had a significant impact on aquaculture. These impacts are causing a drop in fisheries and aquaculture production [19].

\subsubsection{Processors}

The fisheries and aquaculture sector are heavily reliant on the food service industry, which has, itself, been severely impacted by recent changes. Restaurants, hotels, and canteens have been closed due to the adoption of lockdown in many regions throughout the world, which has resulted in a decline in the activity of fish wholesalers [46]. Because of the many logistical challenges previously discussed, the raw materials for frozen, prepacked, and canned fish and fish products have also been unavailable. The products have been exposed to loss, quality change, and higher costs for exporters, processors, merchants, and importers due to transportation bottlenecks and delays [6]. 


\subsubsection{Cold Storage Facilities}

Fishers in poverty-prone regions with limited infrastructure and market linkages sell the majority of their catches to local consumers on the local market. This contributes to the low fish prices and low income for fishers and the COVID-19 outbreak has exacerbated this problem [48]. As fish is highly perishable and storage facilities are barely available, it has often spoiled. This has resulted in both fishers and fish sellers having to discard a substantial portion of rotten fish [53]. Establishing a cold storage business in fishingoriented areas could be one answer. A suitable cold storage facility could boost the fishing industry's efficiency and output during the pandemic. As a result of the influence of COVID-19, the number of available cold storage facilities is rapidly reducing due to the increased demand [48].

\subsubsection{Difficulties in International Trade}

Due to airline limitations and the extended quarantine periods, fishing crews have been unable to depart from their homes. The COVID-19 virus could spread quickly among crew members and medical help may be challenging to obtain [26]. The majority of fishers are migratory and many are frequent international visitors to foreign fishing towns; these traits increase the chance of COVID-19 spreading and causing problems for crew members [23].

\subsubsection{Coping Strategies}

Different actors within the fisheries and aquaculture sector have adopted varying coping strategies in order to lessen the impact of COVID-19 and bolster their own resilience. Some of the common responses adopted by these actors are presented below:

- China's government launched the National Fish Demand and Supply Information Platform, under the authority of the Ministry of Agriculture and Rural Affairs. This has aided many small businesses and large corporations in selling their products [14].

- In India, a community radio station was established to link fishers with doctors, municipal workers, and police officers to react to fisherman's worries and inquiries regarding the pandemic [33].

- In Indonesia, fishers have been substituting other species for soft-shell crab as a source of export income. Shrimp, squid, and various other species have been substituted [16].

- The Department of Agriculture in the Philippines launched the Food Lane Conduct Pass to ensure the continued flow and supply of agricultural, food, and fishery products [35].

- In Bangladesh, the government declared incentive package to overcome the damage to the fisheries and aquaculture sector. These mitigation packages help fish farmers, various other actors within the supply chain and the overall sector to enhance their resilience $[19,54]$. Furthermore, the Bangladesh Fisheries Development Corporation (BFDC) has started selling fish online within Dhaka Metropolitan City [55].

\subsection{Policy Recommendations}

While the pandemic is still emerging, effective short- and long-term solutions must be coordinated, planned, and implemented for the survival of fishery-dependent people; particularly those in developing countries in which a significant number of people rely on this sector. Small-scale fishermen, coastal fishing communities, and aquaculture producers require the immediate mobilization of resources and inputs. While actors in the fish value chain have deployed a number of diverse responses in order to cope with the short-term impacts of the COVID-19 pandemic, the findings of this study recommend the following policy measures to further mitigate the short-term impacts of COVID-19 as well as to support the longer-term recovery and enhance the fisheries sector's resilience to future shocks and stresses.

An efficient management system should be introduced to address the needs, gaps, and problems in the fisheries sector through the use of economic recovery packages. The design and implementation of a rescue policy package should be tailored to local needs, with recovery actions prioritized for the short, medium, and long terms [56]. Particular priority should 
be given to the households in which someone has fallen sick to COVID-19, as these were often severely affected by issues surrounding agricultural production, whereas households that were affected by travel restrictions, market closures, etc. suffered relatively less-severe impacts [57]. The design of the rescue policy packages should consider the following:

(a) Smallholder fishers, whose livelihoods have been most heavily impacted by COVID-19, need food and cash for their survival and continued production. Loan forgiveness or new loans at subsidized rates for small-scale fishers and farmers could be included in the provision. Support in the form of food and cash should continue for 6-12 months in order to overcome the situation.

(b) The restoration of the fishing sector, including fishing activities, production, processing, and trade, can be aided by an emergency relief loan. The distribution of relief loans should be based on the operational relevance and needs involved. The selection of the beneficiaries must be carried out transparently. Existing financial institutions and credit schemes, both public and private, could play an essential role in distributing financial resources quickly and efficiently.

(c) The resumption of fresh product and seafood processing necessitates a relevant national agency's safety and health inspection certification. Health and safety regulations must be implemented for fisheries' products and processing facilities. As an immediate response, the safeguard of workers against COVID-19 and exploitation should be properly enforced. The government and development partners need to work to facilitate market access for the producers. The resumption of cross-border trade and the export of fish and fish products may necessitate bilateral assistance.

(d) The inability of smallholder fishers to sell their produce during the COVID-19 pandemic warrants the strengthening of the fish value chains, including the development of road and market infrastructure, cold storage facilities, transport systems, farmer to market linkages, and the increased flow of market information. The use of digital tools has already helped to shorten these value chains, making fish and aquaculture trades more 'infection safe'. Policies and programs designed to promote the use of digital tools could strengthen the resilience of fisheries and aquaculture systems.

(e) The governments of many countries have already launched packages designed to mitigate the losses in the fisheries sector. This money can be used to support training and technology acquisition for extension services, fish breeding and fish ponds. It has also enabled the distribution of fish seed stock and fingerlings. Initiatives designed to support the development of new markets and the promotion of seafood consumption domestically have already been implemented by governments in Australia, Japan, the United Kingdom, Chile, China, Peru, Thailand and Indonesia.

(f) The process of gaining knowledge from the losses and damages that have been incurred must be supported across all relevant institutions and sectors. Existing development projects and programs can offer perspectives that draw on experience from within the field. This knowledge synthesis must invite and allow the participation of fishing communities and community-based organizations (CBOs) that have faced and overcome obstacles and crises.

(g) Development organization can help with the re-orientation and flexibility of financing programs and the targeting of support to smallholders and rural fishing communities. Buyers should maintain contact with the suppliers that obtain their products from small fishers. Distributors should ensure that their trading patterns are maintained and that smallholders have access to them in order to distribute their products.

(h) The fishing season could be extended on a conditional basis. Reopening processing facilities and allowing workers to enter those processing facilities necessitates safe working conditions and reasonable pay rates. The imposition of preventive health measures for workers and fishers is a practical requirement for access to health services. 


\section{Conclusions}

COVID-19 has impacted almost all sectors of the global economy. Due to the continuous, restrictive measures imposed on travel, movement, and transportation, communities and stakeholders in the fisheries and aquaculture sector have been negatively affected. The present study reveals that fishermen and other supply chain actors have experienced several obstacles owing to COVID-19, such as input supply limitation, lack of technical support, inability to market their products, lack of transportation to the market, export restrictions on fish and fishery products, and low fish prices. Many small-scale fishermen have faced food insecurity due to COVID-19. COVID-19 has exposed pre-existing vulnerabilities and limited resilience by disrupting fish supply and demand, fish distribution, labor, and production, therefore posing a threat to small-scale fishing households' well-being. Fish farmers have also confronted several obstacles, including a shortage of inputs and technical assistance, market difficulty, transportation issues, and low prices. These difficulties have resulted in inadequate output, unanticipated stock retention, loss of returns and food insecurity. Fish farmers may well lose interest in producing fish and related items. Many COVID-19-related restrictions have contributed to a significant gap between demand and supply in the fish food chain, resulting in a decline of the fishery industry. This study recommends measures to address the COVID-19 crisis and its impacts on aquaculture and the fish food chain, in particular suggesting the provision of interest-free loans for the fisheries sector's stakeholders, which could help to enhance their resilience. Looking forward, this study also suggests future lines of research which investigate the key impacts of COVID-19 on each stakeholder involved in the fish and aquaculture sector.

Author Contributions: G.M.M.A. and H.B. initiated the study. G.M.M.A. and M.N.I.S. collected the data. G.M.M.A., H.B. and M.N.I.S. processed the data and performed analysis. G.M.M.A., M.N.I.S., M.G., H.B. and D.N. wrote and revised the manuscript. All authors have read and agreed to the published version of the manuscript.

Funding: This study was conducted under the CGIAR COVID-19 Hub which is supported by contributors to the CGIAR Trust Fund.

Institutional Review Board Statement: Not applicable.

Informed Consent Statement: Not applicable.

Data Availability Statement: Not applicable.

Conflicts of Interest: The authors declare no conflict of interest.

\section{References}

1. Oyenuga, A. Perspectives on the impact of the COVID-19 pandemic on the global and African maritime transport sectors, and the potential implications for Africa's maritime governance. WMU J. Marit. Aff. 2021, 20, 215-245. [CrossRef]

2. FAO. The Impact of COVID-19 on Fisheries and Aquaculture Food Systems, Possible Responses; FAO: Food and Agriculture Organization of the United Nations: Rome, Italy, 2021; ISBN 978-92-5-133768-4.

3. FAO. Summary of the Impacts of the COVID-19 Pandemic on the Fisheries and Acquaculture Sector; FAO: Rome, Italy, 2020; ISBN 978-92-5-132789-0. [CrossRef]

4. Mandal, S.C.; Boidya, P.; Haque, M.I.M.; Hossain, A.; Shams, Z.; Mamun, A.A. The impact of the COVID-19 pandemic on fish consumption and household food security in Dhaka city, Bangladesh. Glob. Food Sec. 2021, 29, 100526. [CrossRef]

5. Farrell, P.; Thow, A.M.; Wate, J.T.; Nonga, N.; Vatucawaqa, P.; Brewer, T.; Sharp, M.K.; Farmery, A.; Trevena, H.; Reeve, E.; et al. COVID-19 and Pacific food system resilience: Opportunities to build a robust response. Food Secur. 2020, 12, 783-791. [CrossRef]

6. $\quad$ Fiorella, K.J.; Bageant, E.R.; Mojica, L.; Obuya, J.A.; Ochieng, J.; Olela, P.; Otuo, P.W.; Onyango, H.O.; Aura, C.M.; Okronipa, H. Small-scale fishing households facing COVID-19: The case of Lake Victoria, Kenya. Fish. Res. 2021, 237, 105856. [CrossRef]

7. Love, D.C.; Allison, E.H.; Asche, F.; Belton, B.; Cottrell, R.S.; Froehlich, H.E.; Gephart, J.A.; Hicks, C.C.; Little, D.C.; Nussbaumer, E.M.; et al. Emerging COVID-19 impacts, responses, and lessons for building resilience in the seafood system. Glob. Food Sec. 2021, 28, 100494. [CrossRef]

8. Giannakis, E.; Hadjioannou, L.; Jimenez, C.; Papageorgiou, M.; Karonias, A.; Petrou, A. Economic consequences of coronavirus disease (COVID-19) on fisheries in the eastern mediterranean (Cyprus). Sustainability 2020, 12, 9406. [CrossRef]

9. Ferrer, A.J.G.; Pomeroy, R.; Akester, M.J.; Muawanah, U.; Chumchuen, W.; Lee, W.C.; Hai, P.G.; Viswanathan, K.K. COVID-19 and small-scale fisheries in Southeast Asia: Impacts and responses. Asian Fish. Sci. 2021, 34, 99-113. [CrossRef] 
10. Waiho, K.; Fazhan, H.; Ishak, S.D.; Kasan, N.A.; Liew, H.J.; Norainy, M.H.; Ikhwanuddin, M. Potential impacts of COVID-19 on the aquaculture sector of Malaysia and its coping strategies. Aquac. Rep. 2020, 18, 100450. [CrossRef]

11. Plagányi, É.; Deng, R.A.; Tonks, M.; Murphy, N.; Pascoe, S.; Edgar, S.; Salee, K.; Hutton, T.; Blamey, L.; Dutra, L. Indirect impacts of COVID-19 on a tropical lobster fishery's harvest strategy and supply chain. Front. Mar. Sci. 2021, 8, 1-14. [CrossRef]

12. Stokes, G.L.; Lynch, A.J.; Lowe, B.S.; Funge-Smith, S.; Valbo-Jørgensen, J.; Smidt, S.J. COVID-19 pandemic impacts on global inland fisheries. Proc. Natl. Acad. Sci. USA 2020, 117, 29419-29421. [CrossRef] [PubMed]

13. Smith, S.L.; Golden, A.S.; Ramenzoni, V.; Zemeckis, D.R.; Jensen, O.P. Adaptation and resilience of commercial fishers in the Northeast United States during the early stages of the COVID-19 pandemic. PLoS ONE 2020, 15, e243886. [CrossRef]

14. Newton, R.; Zhang, W.; Xian, Z.; McAdam, B.; Little, D.C. Intensification, regulation and diversification: The changing face of inland aquaculture in China. Ambio 2021, 50, 1739-1756. [CrossRef] [PubMed]

15. Webb, C. Giving everyone a fish: COVID-19 and the new politics of distribution. Anthropologica 2021, 63, 1-16. [CrossRef]

16. Wiradana, P.A.; Widhiantara, I.G.; Pradisty, N.A.; Mukti, A.T. The impact of COVID-19 on Indonesian fisheries conditions: Opinion of current status and recommendations. IOP Conf. Ser. Earth Environ. Sci. 2021, 718, 012020. [CrossRef]

17. Chanrachkij, I.; Laongmanee, P.; Lanmeen, J.; Suasi, T.; Sornkliang, J.; Tiaye, R.; Yasook, N.; Putsa, S. Severity of the impacts of COVID-19 pandemic on small-scale fisheries of Thailand: A preliminary assessment. Fish People 2020, $18,43-47$.

18. Islam, M.M.; Khan, M.I.; Barman, A. Impact of novel coronavirus pandemic on aquaculture and fisheries in developing countries and sustainable recovery plans: Case of Bangladesh. Mar. Policy 2021, 131, 104611. [CrossRef]

19. Sunny, A.R.; Sazzad, S.A.; Prodhan, S.H.; Ashrafuzzaman, M.; Datta, G.C.; Sarker, A.K.; Rahman, M.; Mithun, M.H. Assessing impacts of COVID-19 on aquatic food system and small-scale fisheries in Bangladesh. Mar. Policy 2021, 126, 104422. [CrossRef] [PubMed]

20. Campbell, S.J.; Jakub, R.; Valdivia, A.; Setiawan, H.; Setiawan, A.; Cox, C.; Kiyo, A.; Darman; Djafar, L.F.; Rosa, E.; et al. Immediate impact of COVID-19 across tropical small-scale fishing communities. Ocean Coast. Manag. 2021, 200, 105485. [CrossRef]

21. Okyere, I.; Chuku, E.O.; Ekumah, B.; Angnuureng, D.B.; Boakye-Appiah, J.K.; Mills, D.J.; Babanawo, R.; Asare, N.K.; Aheto, D.W.; Crawford, B. Physical distancing and risk of COVID-19 in small-scale fisheries: A remote sensing assessment in coastal Ghana. Sci. Rep. 2020, 10, 1-13. [CrossRef]

22. Sarà, G.; Mangano, M.C.; Berlino, M.; Corbari, L.; Lucchese, M.; Milisenda, G.; Terzo, S.; Azaza, M.S.; Babarro, J.M.F.; Bakiu, R.; et al. The synergistic impacts of anthropogenic stressors and COVID-19 on aquaculture: A current global perspective. Rev. Fish. Sci. Aquac. 2021, 1-13. [CrossRef]

23. Mangubhai, S.; Nand, Y.; Reddy, C.; Jagadish, A. Politics of vulnerability: Impacts of COVID-19 and Cyclone Harold on Indo-Fijians engaged in small-scale fisheries. Environ. Sci. Policy 2021, 120, 195-203. [CrossRef]

24. Hamzah, A.; Nurdin, H.S. Economic resilience of fishermen community during COVID-19 pandemic. IOP Conf. Ser. Earth Environ. Sci. 2021, 715, 012062. [CrossRef]

25. White, E.R.; Froehlich, H.E.; Gephart, J.A.; Cottrell, R.S.; Branch, T.A.; Agrawal Bejarano, R.; Baum, J.K. Early effects of COVID-19 on US fisheries and seafood consumption. Fish Fish. 2021, 22, 232-239. [CrossRef] [PubMed]

26. Ruiz-Salmón, I.; Fernández-Ríos, A.; Campos, C.; Laso, J.; Margallo, M.; Aldaco, R. Fishing and seafood sector in the time of COVID-19: Considerations for local and global opportunities and responses. Curr. Opin. Environ. Sci. Health 2021, $23,100286$. [CrossRef]

27. Fink, A. Conducting Research Literature Reviews: From the Internet to Paper, 2nd ed.; SAGE: Thousand Oaks, CA, USA, 2005.

28. Moher, D.; Liberati, A.; Tetzlaff, J.; Altman, D.G. Preferred reporting items for systematic reviews and meta-analyses: The PRISMA statement. PLoS Med. 2009, 6, e1000097. [CrossRef] [PubMed]

29. Workie, E.; Mackolil, J.; Nyika, J.; Ramadas, S. Deciphering the impact of COVID-19 pandemic on food security, agriculture, and livelihoods: A review of the evidence from developing countries. Curr. Res. Environ. Sustain. 2020, 2, 100014. [CrossRef]

30. Simmance, F.A.; Simmance, A.B.; Kolding, J.; Schreckenberg, K.; Tompkins, E.; Poppy, G.; Nagoli, J. A photovoice assessment for illuminating the role of inland fisheries to livelihoods and the local challenges experienced through the lens of fishers in a climate-driven lake of Malawi. Ambio 2021. [CrossRef]

31. Belton, B. Impacts of COVID-19 on Aquatic Food Supply Chains in Egypt; CGIAR Research Program on Fish Agri-Food Systems: Penang, Malaysia, 2020.

32. Kumaran, M.; Geetha, R.; Antony, J.; Vasagam, K.P.K.; Anand, P.R.; Ravisankar, T.; Angel, J.R.J.; De, D.; Muralidhar, M.; Patil, P.K.; et al. Prospective impact of Corona virus disease (COVID-19) related lockdown on shrimp aquaculture sector in India-A sectoral assessment. Aquaculture 2021, 531, 735922. [CrossRef]

33. Seshagiri, B.; Nagireddy, M.; Raju, V.R.; Nagireddy, S.; Rangacharyulu, P.; Rathod, R.; Ratnaprakash, V. Impact of nationwide lockdown on freshwater aquaculture in Andhra Pradesh, India. Int. J. Fish. Aquat. Stud. 2020, 8, 377-384. [CrossRef]

34. Cooke, S.J.; Twardek, W.M.; Lynch, A.J.; Cowx, I.G.; Olden, J.D.; Funge-Smith, S.; Lorenzen, K.; Arlinghaus, R.; Chen, Y.; Weyl, O.L.F.; et al. A global perspective on the influence of the COVID-19 pandemic on freshwater fish biodiversity. Biol. Conserv. 2021, 253, 108932. [CrossRef]

35. Manlosa, A.O.; Hornidge, A.K.; Schlüter, A. Aquaculture-capture fisheries nexus under COVID-19: Impacts, diversity, and social-ecological resilience. Marit. Stud. 2021, 20, 75-85. [CrossRef]

36. Waibel, H.; Grote, U.; Min, S.; Nguyen, T.T.; Praneetvatakul, S. COVID-19 in the greater Mekong Subregion: How resilient are rural households? Food Secur. 2020, 12, 779-782. [CrossRef] [PubMed] 
37. Andrews, N.; Bennett, N.J.; Le Billon, P.; Green, S.J.; Cisneros-Montemayor, A.M.; Amongin, S.; Gray, N.J.; Sumaila, U.R. Oil, fisheries and coastal communities: A review of impacts on the environment, livelihoods, space and governance. Energy Res. Soc. Sci. 2021, 75. [CrossRef]

38. Shenoy, L.; Rajpathak, S. The Impact of COVID-19 on Fisheries and Aquaculture-A Global Assessment from the Perspective of Regional Fishery Bodies; FAO: Rome, Italy, 2020; ISBN 978-92-5-132735-7.

39. Marschke, M.; Vandergeest, P.; Havice, E.; Kadfak, A.; Duker, P.; Isopescu, I.; MacDonnell, M. COVID-19, instability and migrant fish workers in Asia. Marit. Stud. 2021, 20, 87-99. [CrossRef]

40. Asante, E.O.; Blankson, G.K.; Sabau, G. Building back sustainably: COVID-19 impact and adaptation in newfoundland and labrador fisheries. Sustainability 2021, 13, 2219. [CrossRef]

41. Fernández-González, R.; Pérez-Pérez, M.I.; Pérez-Vas, R. Impact of the COVID-19 crisis: Analysis of the fishing and shellfishing sectors performance in Galicia (Spain). Mar. Pollut. Bull. 2021, 169. [CrossRef]

42. Hasan, N.A.; Heal, R.D.; Bashar, A.; Bablee, A.L.; Haque, M.M. Impacts of COVID-19 on the finfish aquaculture industry of Bangladesh: A case study. Mar. Policy 2021, 130, 104577. [CrossRef]

43. Kaewnuratchadasorn, P.; Smithrithee, M.; Sato, A.; Wanchana, W.; Tongdee, N.; Sulit, V.T. Capturing the Impacts of COVID-19 on the Fisheries Value Chain of Southeast Asia. Fish People 2020, 18, 2-8. Available online: http:/ / repository.seafdec.org/handle/20 $.500 .12066 / 6557$ (accessed on 15 September 2021).

44. Paradis, Y.; Bernatchez, S.; Lapointe, D.; Cooke, S.J. Can you fish in a pandemic? An overview of recreational fishing management policies in North America during the COVID-19 crisis. Fisheries 2021, 46, 81-85. [CrossRef]

45. Can, M.F.; Şimşek, E.; Demirci, A.; Demirci, S.; Akar, Ö. The evaluation of the early impacts of the COVID-19 pandemic on the export of fishery commodities of Turkey. Mar. Life Sci. 2020, 2, 13-17.

46. Zabir, A.A.; Mahmud, A.; Islam, M.A.; Antor, S.C.; Yasmin, F.; Dasgupta, A. COVID-19 and Food Supply in Bangladesh: A Review. South Asian J. Soc. Stud. Econ. 2021, 10, 15-23. [CrossRef]

47. Bennett, N.J.; Finkbeiner, E.M.; Ban, N.C.; Belhabib, D.; Jupiter, S.D.; Kittinger, J.N.; Mangubhai, S.; Scholtens, J.; Gill, D.; Christie, P. The COVID-19 pandemic, small-scale fisheries and coastal fishing communities. Coast. Manag. 2020, 48, 336-347. [CrossRef]

48. Fahlevi, H.; Chan, S.; Hasibuan, P.; Fadli, N.; Sofyan, S.E.; Rianjuanda; Syukri, M.; Saidi, T.; Dawood, R. The feasibility of a cold storage facility for fish in Aceh during the COVID-19 pandemic. IOP Conf. Ser. Earth Environ. Sci. 2021, 674, 012047. [CrossRef]

49. Iese, V.; Wairiu, M.; Hickey, G.M.; Ugalde, D.; Hinge Salili, D.; Walenenea, J.; Tabe, T.; Keremama, M.; Teva, C.; Navunicagi, O.; et al. Impacts of COVID-19 on agriculture and food systems in Pacific Island countries (PICs): Evidence from communities in Fiji and Solomon Islands. Agric. Syst. 2021, 190, 103099. [CrossRef]

50. Zorriehzahra, M.J.; Hassantabar, F.; Ziarati, M. The impacts of COVID-19 pandemic on aquatic food production: A review. Iran. J. Aquat. Anim. Heal. 2020, 6, 15-22.

51. Belton, B.; Rosen, L.; Middleton, L.; Ghazali, S.; Mamun, A.A.; Shieh, J.; Noronha, H.S.; Dhar, G.; Ilyas, M.; Price, C.; et al. COVID-19 impacts and adaptations in Asia and Africa's aquatic food value chains. Mar. Policy 2021, 129, 104523. [CrossRef]

52. Hidayati, I.; Putri, I.; Ghani, M.; Situmorang, A. Widayatun Small-scale fishing families and their daily multiple-stressor on climate change and COVID-19: Preliminary findings. IOP Conf. Ser. Earth Environ. Sci. 2021, 739, 012047. [CrossRef]

53. Amjath-Babu, T.S.; Krupnik, T.J.; Thilsted, S.H.; McDonald, A.J. Key indicators for monitoring food system disruptions caused by the COVID-19 pandemic: Insights from Bangladesh towards effective response. Food Secur. 2020, 12, 761-768. [CrossRef] [PubMed]

54. Mamun, A.A.; Shieh, J.; Belton, B. Qualitative Assessment of COVID-19 Impacts on Aquatic Food Value Chains in Bangladesh; Program Report; CGIAR Research Program on Fish Agri-Food Systems: Penang, Malaysia, 2020.

55. BFDC. BFDC Online Fish-Largest Online Fish Market in Bangladesh 2021. pp. 1-2. Available online: https://bfdconlinefish.com/ (accessed on 15 September 2021).

56. OECD. COVID-19 Pandemic: Towards a Blue Recovery in Small Island Developing States; OECD Policy Responses to Coronavirus (COVID-19); OECD Publishing: Paris, France, 2021; pp. 1-29. Available online: https://read.oecd-ilibrary.org/view/?ref=1060_1 060174-tnkmsj15ap\&title=COVID-19-pandemic-Towards-a-blue-recovery-in-small-island-developing-states (accessed on 15 September 2021).

57. Gatto, M.; Islam, A.H.M.S. Impacts of COVID-19 on rural livelihoods in Bangladesh: Evidence using panel data. PLoS ONE 2021, in press. [CrossRef] 